\title{
Hydrochemical analysis and evaluation of heavy metals in groundwater: A case study
}

\author{
Fitryaliah Mohd Shahli ${ }^{1}$, Siti Nazahiyah Rahmat ${ }^{*}$, and Siti Nor Aishah Mohd Salleh ${ }^{1}$ \\ ${ }^{1}$ Faculty of Civil and Environmental Engineering,Universiti Tun Hussein Onn Malaysia (UTHM), \\ 86400 Parit Raja, Johor, Malaysia
}

\begin{abstract}
The hydrochemical characteristics and the type of groundwater were identified in order to investigate the elements of major ions of groundwater samples in hydro-meteorology station located in Universiti Tun Hussien Onn Malaysia, UTHM. The objectives of the study were to measure the concentration of major ions and evaluate their chemical compositions. The measured ions were namely sodium $(\mathrm{Na})$, magnesium $(\mathrm{Mg})$, calcium $(\mathrm{Ca})$, potassium $(\mathrm{K})$, chloride $(\mathrm{Cl})$, bicarbonate $\left(\mathrm{HCO}_{3}\right)$, sulfate $\left(\mathrm{SO}_{4}\right)$, heavy metals substance such as zinc $(\mathrm{zn})$, ferum $(\mathrm{Fe})$, copper $(\mathrm{Cu})$, and manganese $(\mathrm{Mn})$. Eight $(8)$ groundwater samples were collected between January 2018 and March 2018 from a tubewell located at the Universiti Tun Hussein Onn Malaysia, Parit Raja, Johor followed by laboratory analyses by using Standard Methods for the Examination of Water and Wastewater. The concentrations of major cations and anions were determined and the concecutive strength were $\mathrm{Na}>\mathrm{Mg}>\mathrm{K}>\mathrm{Ca}$ and $\mathrm{Cl}>\mathrm{HCO}_{3}>\mathrm{SO}$, respectively. Correlations among various pollutants were also observed. Strong correlations $(p<0.01)$ were found between Total Dissolved Solid (TDS) and Electric Conductivity (EC). Both TDS and EC also showed strong positive correlations with $\mathrm{Na}, \mathrm{Mg}$, and $\mathrm{Cl}$ ions. The dispersal of major ions in groundwater was determined using piper diagram. The major cation and anion found were $\mathrm{Na}$ and $\mathrm{Cl}$, respectively. The type of water that predominates in the study area was $\mathrm{Na}-\mathrm{Cl}$ which indicated the groundwater influence from seawater intrusion. Mean concentrations for heavy metals parameters were also identified. The values milligram per litre $(\mathrm{mg} / \mathrm{L})$ were $\mathrm{Mn}(0.20), \mathrm{Cu}(0.01), \mathrm{Fe}(0.50)$ and $\mathrm{Zn}(0.04)$, respectively. Overall, the selected heavy metal parameters which were $\mathrm{Mn}, \mathrm{Cu}, \mathrm{Fe}$ and $\mathrm{Zn}$ met the Recommended Raw Water Standard by Ministry of Health, Malaysia.
\end{abstract}

\section{Introduction}

Malaysia has abundance of water resources and receives an average of $3000 \mathrm{~mm}$ rainfall annually. Despite the general abundance quantities of surface water available to meet the demand, the water shortages have occurred fairly frequent in Malaysia.

\footnotetext{
"Corresponding author: nazahiya@uthm.edu.my
} 
Population growth, municipal development, industrialization, and irrigation of agriculture as well as climate change strengthen the growing demand and pressure on Malaysian water resources thereby enhancing water pollution [1][2]. Besides pollution issues, the water supply especially from dams will not be sufficient for daily use when it is in dry period. Therefore, groundwater is one of the potential sources of water to be used in the event of drought or no other water supply in the area[3][4].

The clay type of soil that is located in the study area make the soil fails to retain much water deep into the ground[5]. However, the groundwater can still be recovered from shallow groundwater. Shallow groundwater is much easier to exploit, but it is vulnerable to pollutants such as heavy metal and its quality is easily influenced by natural water-rock interactions and anthropogenic activities[6]. Thus, shallow groundwater requires more attention and protection before it can be consumed safely. A small disturbance from human such as mining, or natural processes can easily modify the chemical constituents and quality of shallow groundwater. Therefore, the understanding of the hydrogeochemical process and water quality status is a significant component in addressing effective protection measures and implementing sustainable management of shallow groundwater[7].

This study was conducted to investigate the hydrochemical and heavy metal concentration in the study area. Major ions and heavy metal of groundwater samples were analysed and the result was compared with Raw and Drinking Water Quality by Ministry of Health Malaysia[8]. The study could serve as important information for groundwater protection and management in study area.

\section{Study area}

The study area is located at the hydro-meteorology station in Universiti Tun Hussien Onn Malaysia, UTHM, Johor as shown in Fig.1. Generally, the location has flat topography and surrounded with private factory, university buildings (laboratory, class and offices), and golf course. Based on geological map by Department of Mineral and Geoscience Malaysia (JMG) [9] as shown in Fig.2., this study area consisted of continential deposits from marine clay and silt soil. Based on the site observation, wet clay and silt geomaterials can be easily found in study area. The area was found to have high water content derived from high water table of lowland areas. This cause the existing of the material that demonstrated the soft soil phenomenon[10]. Besides, the high rainfall intensity which is commonly occurred in the study area also has contribute the elevation of water table thus helping to the soft soil phenomenon in this location. A study by Abidin et al. [10] was also found that this area consisted of thick clay and silt that suitable for groundwater storage and carriage. However, fine particles of clay and silk soil may course low hydraulic conductivity which influences the effectiveness of groundwater recharge [11].

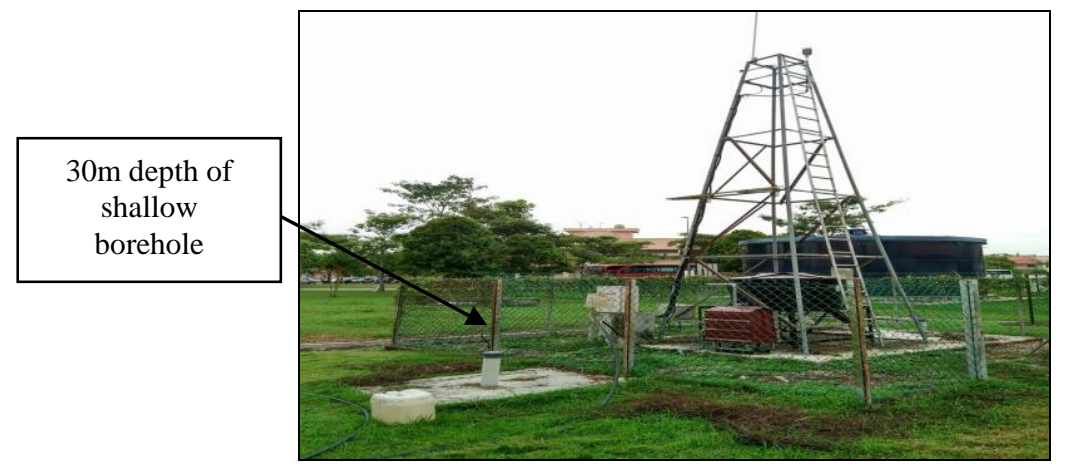

Fig. 1. Hydro-meteorology station in Universiti Tun Hussien Onn Malaysia, UTHM. 


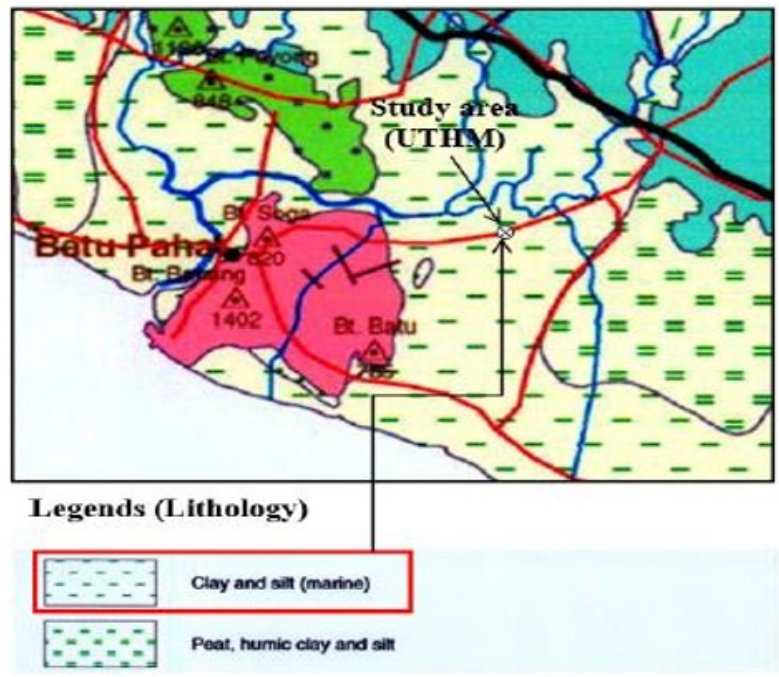

Fig. 2. Geological map of study area by Department of Mineral and Geoscience Malaysia (JMG) [9].

\section{Methodology}

In this study, total of eight (8) groundwater samples were collected from a $30 \mathrm{~m}$ depth shallow borehole to determine major ions which were $\mathrm{Na}, \mathrm{Ca}, \mathrm{Mg}, \mathrm{K}, \mathrm{Cl}, \mathrm{SO}_{4}$, and $\mathrm{HCO}_{3}$. Also heavy metal substances which were $\mathrm{Fe}, \mathrm{Cu}, \mathrm{Zn}$, and $\mathrm{Mn}$. All the sampling and testing procedures followed the Standard Method for the Examination of Water and Wastewater [12]. The duration of sample collection was from January 2018 until March 2018.

Groundwater was pumped out from the borehole for 10 to 15 minutes using purging pumps at a rate of $33.96 \mathrm{~m}^{3} /$ day as shown in Fig. 3. before the sample collection made. Polyethylene teraphthalate (PET) bottles were used to collect the samples. All sampling bottles were washed with diluted nitric acid at $10 \%$ concentration and thoroughly rinsed with distilled water prior to sample collection. In-situ measurement was carried out using a HANNA HI9829, portable multi-parameter meter to measure $\mathrm{pH}$, temperature, electrical conductivity (EC), and total dissolve solid (TDS). For ions and heavy metal measurement, the groundwater samples were filtered using a $0.45 \mu \mathrm{m}$ cellulose acetate memberane and acidified to $\mathrm{pH}<2$ using diluted nitric acid. Then the samples were stored in the cooler box with controlled temperature and immediately brought to the laboratory for further analysis. Flame Atomic Absorption Spectrophotometer (FAAS; PerkinElmer) was used to measure major cation of $\mathrm{Na}, \mathrm{Ca}, \mathrm{K}$, and $\mathrm{Mg}$ while Metrohm Ion Chromatography Machine (IC) was used to measure major cation of $\mathrm{Cl}, \mathrm{SO}_{4}$, and $\mathrm{HCO}_{3}$. For heavy metal concentrations of $\mathrm{Fe}$, $\mathrm{Zn}, \mathrm{Cu}$, and $\mathrm{Mn}$, the instrument of Inductive Couple Plasma Mass Spectrometry (ICP-MS: PerkinElmer) was used to analysed the sample.

The data from laboratory analysis was analysed using statistical analysis. In this study, statistical software IBM SPSS Statistics 20 was used for analysing descriptive statistics and correlation coefficient between variables. Piper diagram was constructed using Geochemist Workbench software to determine the major ions distribution of ground water and determination of water type. 


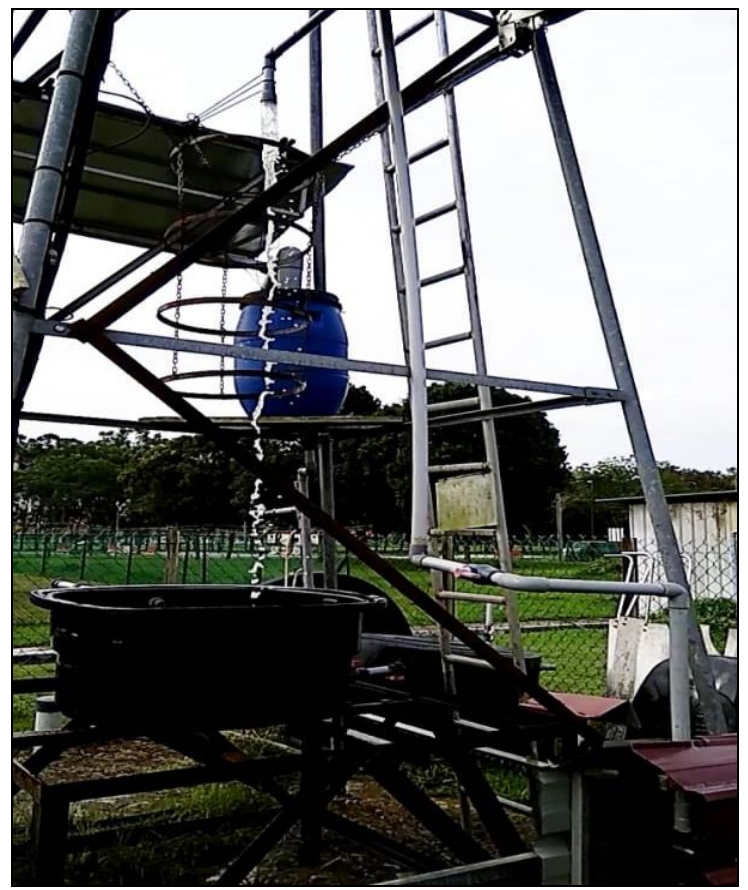

Fig. 3. Groundwater that pumped out from the borehole using purging pumps.

\section{Results and Discussion}

\subsection{Descriptive analysis}

Physiochemical and heavy metal characteristics of collected groundwater samples at study area are shown in table 1 . The $\mathrm{pH}$ value was found out to be natural with mean value of 7.61, with minimum and maximum values at 7.26 and 7.92 respectively. Water that falls within pH 6 until 9 can be considered as natural [13]. According to Raw and Drinking Water Quality Standard [8], the desirable limit of $\mathrm{pH}$ for drinking water is between 6.5 and 8.5. Therefore, all the samples were within the desired limit.

However, the groundwater samples gave high values of TDS that ranged between minimum values of $1924 \mathrm{mg} / \mathrm{l}$ and maximum values of $6359 \mathrm{mg} / \mathrm{l}$. These high values of TDS indicated the groundwater influence from seawater intrusion [2]. The electrical conductivity of the samples also gave high values ranged from $3849 \mu \mathrm{S} / \mathrm{cm}$ to 12710 $\mu \mathrm{S} / \mathrm{cm}$. According to Radojevic and Bashkin [14], EC related to the concentration of ionised substance in water. Thus, high value of EC and TDS in this study area indicated that high mineral content such as inorganic salts and organic matters in the water samples .

The order of major cation concentrations were $\mathrm{Na}>\mathrm{Mg}>\mathrm{K}>\mathrm{Ca}$ while anion concentration were $\mathrm{Cl}>\mathrm{HCO}_{3}>\mathrm{SO}_{4}$. The $\mathrm{Na}$ and $\mathrm{Cl}$ were found to be the most abundance cation and anion in the study area. This due to the type of soil, which was an continential deposits from marine clay and silt soil [10]. 
Table 1. Mean \pm std. deviation, minimum, and maximum value of physiochemical analysis of groundwater samples at hydro-meteorology station, UTHM.

\begin{tabular}{|l|c|c|c|}
\hline & $\begin{array}{c}\text { Mean } \pm \text { Std. } \\
\text { Deviation }\end{array}$ & Minimum & Maximum \\
\hline $\mathrm{pH}$ & $7.61 \pm 0.26$ & 7.26 & 7.92 \\
\hline Temperature & $20.72 \pm 4.00$ & 14.75 & 25.19 \\
\hline Conductivity $(\mathrm{EC})$ & $10215.88 \pm 2846.04$ & 3849.00 & 12710.00 \\
\hline $\mathrm{DO}$ & $7.56 \pm 2.83$ & 3.77 & 12.02 \\
\hline $\mathrm{TDS}$ & $5108.50 \pm 1424.03$ & 1924.00 & 6359.00 \\
\hline Sodium $(\mathrm{Na})$ & $2024.59 \pm 602.74$ & 888.70 & 2999.00 \\
\hline Calcium $(\mathrm{Ca})$ & $134.61 \pm 12.16$ & 113.30 & 149.20 \\
\hline Magnesium $(\mathrm{Mg})$ & $267.14 \pm 92.12$ & 83.41 & 366.70 \\
\hline Potassium $(\mathrm{K})$ & $167.57 \pm 119.02$ & 88.60 & 359.10 \\
\hline Bicarbonate $\left(\mathrm{HCO}_{3}\right)$ & $609.63 \pm 98.93$ & 468.00 & 784.00 \\
\hline Chloride $(\mathrm{Cl})$ & $3261.45 \pm 964.99$ & 1118.14 & 3978.74 \\
\hline Sulfate $\left(\mathrm{SO}_{4}\right)$ & $141.60 \pm 37.58$ & 60.43 & 177.91 \\
\hline
\end{tabular}

\subsection{Correlation}

Table 2 shows the correlation coefficient between in-situ parameters, major ions parameters, and heavy metals parameters. The results from each variable parameters show very high positive correlation between EC and TDS $(\mathrm{r}=1.00, \mathrm{p}<0.01)$ due to the constitution of ions and other organic and inorganic substances in water [14]. TDS showed high positive correlation with $\mathrm{Na}, \mathrm{Mg}, \mathrm{Cl}$, and $\mathrm{SO}_{4}$ with $(\mathrm{r}=0.907,0.957,0.918,0.991$; $\mathrm{p}<0.01)$ respectively. $\mathrm{EC}$ also showed high positive correlation with $\mathrm{Na}, \mathrm{Mg}, \mathrm{Cl}$ and $\mathrm{SO}_{4}$ with value of $(\mathrm{r}=0.907,0.957,0.918,0.991 ; \mathrm{p}<0.01)$, respectively. This suggested that TDS and EC were controlled by these ions [15]. Mg also posed strong correlation with $\mathrm{Na}$, $\mathrm{Cl}$ and $\mathrm{SO}_{4}(\mathrm{r}=0.877,0.909$ and $0.979 ; \mathrm{p}<0.01)$.

\subsection{Groundwater classification}

The classification of groundwater types was based on a trilinear Piper diagram [16], where all major ions were used for the classification. Based on Fig. 4., the distribution of major ions were identified as $\mathrm{Na}-\mathrm{Cl}$ which were marine and deep ancient ground water type [17]. The dominant ions were $\mathrm{Na}$ and $\mathrm{Cl}$ with average value of $2024.59 \mathrm{mg} / \mathrm{l}$ and $3261.45 \mathrm{mg} / \mathrm{l}$, respectively. The groundwater samples were characterized by high EC and TDS. According to Samsudin et al. [18], ancient seawater that was trapped within the sediment long time ago might influence the groundwater type and cheracteristic. 


\begin{tabular}{|c|c|c|c|c|c|c|c|c|c|c|c|c|c|c|c|c|c|}
\hline సี & $\frac{9}{\tilde{m}}$ & חิ & $\frac{8}{0}$ & 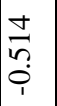 & 웅 & 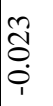 & \begin{tabular}{l|}
$\infty$ \\
0 \\
0 \\
\multirow{0}{0}{} \\
0
\end{tabular} & 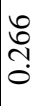 & 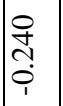 & $\begin{array}{l}0 \\
0 \\
0 \\
0 \\
0 \\
1\end{array}$ & & $\frac{8}{0}$ & $\stackrel{0}{0}$ & $\begin{array}{l}\infty \\
0 \\
0 \\
0 \\
0\end{array}$ & $\begin{array}{l}* \\
0 \\
\infty \\
\infty \\
0 \\
0\end{array}$ & - & \\
\hline$\tilde{E}$ & $\begin{array}{l}\infty \\
2 \\
0 \\
0 \\
1\end{array}$ & \begin{tabular}{l}
$\stackrel{0}{0}$ \\
\multirow{0}{1}{} \\
0
\end{tabular} & ro & $\mid \begin{array}{l}n \\
0 \\
0 \\
0 \\
1\end{array}$ & $\begin{array}{l}\infty \\
0 \\
n \\
0 \\
0\end{array}$ & 衤 & in & 若 & 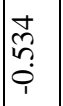 & $\mid \begin{array}{l}7 \\
0 \\
0 \\
0 \\
1\end{array}$ & 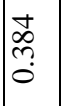 & $\begin{array}{l}\text { त } \\
\text { nุ } \\
0\end{array}$ & م & 命 & - & & \\
\hline$\Sigma$ & $\begin{array}{l}\infty \\
0 \\
0 \\
1\end{array}$ & $\ddot{n}$ & 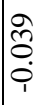 & \begin{tabular}{|l|}
$n$ \\
$n$ \\
$n$ \\
$i$ \\
$i$
\end{tabular} & $\begin{array}{l}\infty \\
0 \\
0 \\
0 \\
1\end{array}$ & 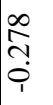 & 我 & $\underset{⿱ 亠 䒑}{0}$ & 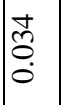 & $\begin{array}{l}2 \\
0 \\
0 \\
0 \\
1\end{array}$ & ஜ & ڤิ & 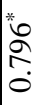 & - & & & \\
\hline İ & $\begin{array}{l}0 \\
0 \\
0 \\
0 \\
1\end{array}$ & ?ִ & 宊 & $\stackrel{1}{a}$ & 导 & $\frac{1}{2}$ & $\mid \begin{array}{l}8 \\
0 \\
\vdots \\
0 \\
0\end{array}$ & 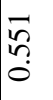 & $\begin{array}{l}2 \\
\infty \\
m \\
0 \\
\end{array}$ & 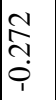 & 苛 & \begin{tabular}{l}
\multirow{H}{*}{} \\
$\stackrel{5}{0}$ \\
0
\end{tabular} & - & & & & \\
\hline ঠ઼ & na & $\frac{n}{n}$ & बू. & 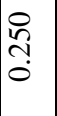 & बू. & 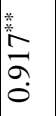 & $\frac{a}{\partial}$ & 商 & $\begin{array}{l}n \\
\ddot{b} \\
0 \\
i\end{array}$ & $\begin{array}{l}n \\
8 \\
0 \\
0 \\
0\end{array}$ & 啇 & - & & & & & \\
\hline $\bar{\tau}$ & $\frac{\infty}{\infty}$ & : & $\frac{\infty}{a}$ & $\exists$ & $\frac{*}{0}$ & $\mid \begin{array}{l}3 \\
0 \\
\infty \\
\infty \\
0 \\
0\end{array}$ & 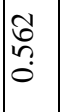 & 参 & 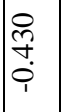 & 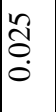 & - & & & & & & \\
\hline$\overbrace{0}^{0}$ & 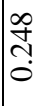 & స̂̀ & 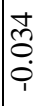 & Iิ & $\begin{array}{l}n \\
\tilde{\theta} \\
0 \\
0 \\
1\end{array}$ & $\mid \begin{array}{l}n \\
0 \\
0 \\
0 \\
1\end{array}$ & 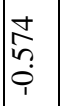 & N̂̀ & $\stackrel{1}{0}$ & - & & & & & & & \\
\hline 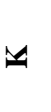 & 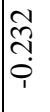 & 悀 & 尊 & 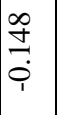 & 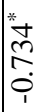 & $\begin{array}{l}\tilde{\hat{C}} \\
0 \\
0 \\
1 \\
1\end{array}$ & $\frac{N}{\Xi}$ & $\begin{array}{l}\text { त्र } \\
0 \\
0 \\
0\end{array}$ & - & & & & & & & & \\
\hline$\sum^{\infty 0}$ & స̃ & ñ & 密 & 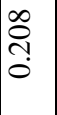 & 番 & 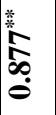 & ññ & - & & & & & & & & & \\
\hline שี & $\begin{array}{l}\text { त̂. } \\
0 \\
0 \\
1\end{array}$ & $\stackrel{*}{=}$ & $\stackrel{n}{\infty}$ & 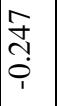 & m. & 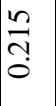 & - & & & & & & & & & & \\
\hline$\tilde{z}$ & $\frac{\infty}{\stackrel{\infty}{-}}$ & 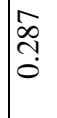 & 略 & $\mid \begin{array}{c}1 \\
\hat{0} \\
0 \\
0 \\
0\end{array}$ & 养 & - & & & & & & & & & & & \\
\hline Ô & ֶิ & 㝘 & 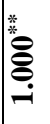 & 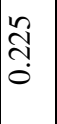 & - & & & & & & & & & & & & 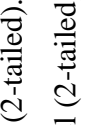 \\
\hline ஜ̊ & \begin{tabular}{l}
$*$ \\
\multirow{2}{*}{} \\
$\stackrel{2}{0}$ \\
0
\end{tabular} & 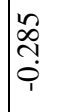 & ڤ̃ & - & & & & & & & & & & & & & $\begin{array}{ll}\frac{0}{0} & \frac{\partial}{1} \\
\vdots & 0 \\
0 & 0 \\
0 & 0\end{array}$ \\
\hline U. & ڤิ & 㝘 & - & & & & & & & & & & & & & & 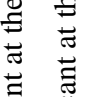 \\
\hline 률 & 愛 & - & & & & & & & & & & & & & & & 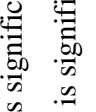 \\
\hline 要 & - & & & & & & & & & & & & & & & & 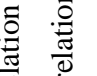 \\
\hline & $\frac{\pi}{2}$ & 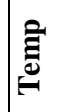 & 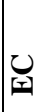 & ○ & $\hat{\theta}$ & 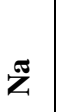 & שే & $\Sigma$ & 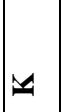 & $\stackrel{0}{0}$ & $\bar{v}$ & Ó & 壵 & 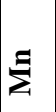 & $\tilde{E}$ & $\mathbf{N}$ & 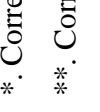 \\
\hline
\end{tabular}



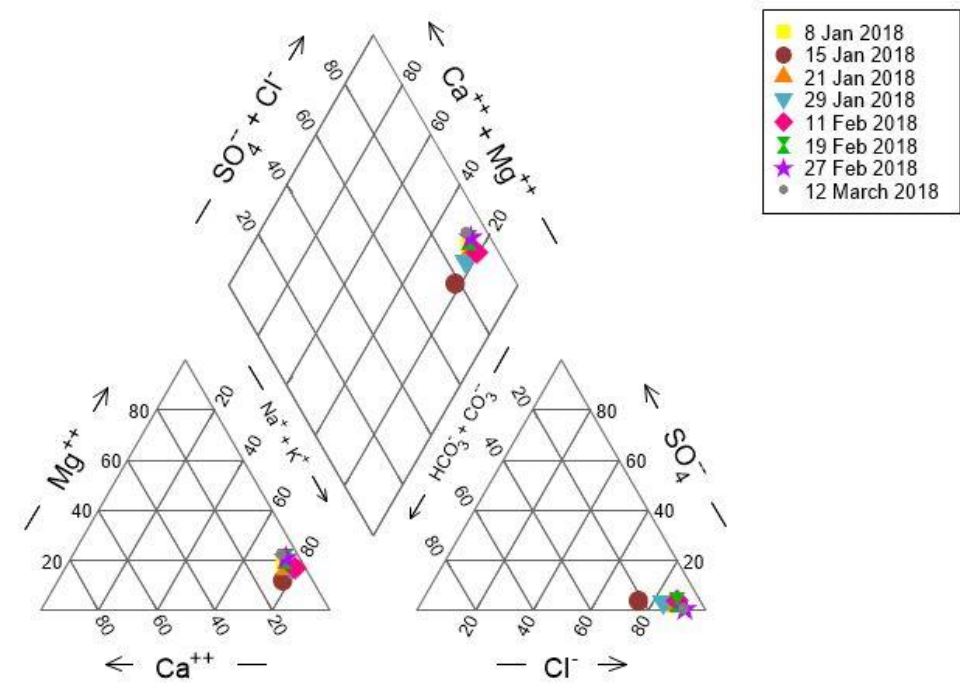

Fig. 4. The distribution of major ions using a piper plot and the determination of water type.

\subsection{Heavy metal anaysis}

Based on Table 3, the dissolved concentrations of heavy metal substances were determined using mean value of $0.53 \mathrm{mg} / \mathrm{l}$ for $\mathrm{Fe}, 0.21 \mathrm{mg} / \mathrm{l}$ for $\mathrm{Mn}, 0.01 \mathrm{mg} / \mathrm{l}$ for $\mathrm{Cu}$ and $0.04 \mathrm{mg} / \mathrm{l}$ for Zn. All the heavy metal parameters met the requirement of Recommended Raw Water Quality by Ministry of Health Malaysia[8]. Unfortunetely, for Drinking Water Quality Standard [8], only $\mathrm{Cu}$ and $\mathrm{Zn}$ met the standard. The possible source of these metals were from natural processes or man-made influence [19]. Under natural conditions, the dissolve ions in the water are related to the mineral assemblies in rock near the ground surface [20]. Mineral texture, porosity, composition, and regional structure of rock also influenced the presence of heavy metals in the groundwater [20]. In other hand, man-made activities such as factories, dumping, and piping services also contribute to the variations of the heavy metal concentration[21]. From the observation, there were factories related to the chemical adhesive and wood based product near the study area, which directly or indirectly attributed to the contamination of the groundwater.

Table 3. The concentration values of heavy metals.

\begin{tabular}{lccc}
\hline & $\begin{array}{c}\text { Mean value } \\
(\mathbf{m g} / \mathbf{l})\end{array}$ & $\begin{array}{c}\text { Recommended } \\
\text { Raw Water } \\
\text { Quality } \\
(\mathbf{m g} / \mathbf{l})\end{array}$ & $\begin{array}{c}\text { Drinking Water } \\
\text { Quality Standards } \\
(\mathbf{m g} / \mathbf{l})\end{array}$ \\
\hline Ferum $(\mathrm{Fe})$ & 0.53 & 1.00 & 0.30 \\
Mangenase $(\mathrm{Mn})$ & 0.20 & 0.20 & 0.10 \\
Cupper $(\mathrm{Cu})$ & 0.01 & 1.00 & 1.00 \\
Zinc $(\mathrm{Zn})$ & 0.04 & 3.00 & 3.00 \\
\hline
\end{tabular}




\section{Conclusion}

It can be concluded that physical, hydrochemical, and heavy metal parameters in the study area were successfully analysed. The orders of major ion concentration were $\mathrm{Na}>\mathrm{Mg}>\mathrm{K}>\mathrm{Ca}$ and $\mathrm{Cl}>\mathrm{HCO}_{3}>\mathrm{SO}_{4}$. Strong correlation exist among TDS and EC due to the composition of the ions in groundwater. Also, strong correlation was found between TDS and $\mathrm{EC}$ with $\mathrm{Na}, \mathrm{Mg}$, and $\mathrm{Cl}$ ions. From the analyses of piper diagram, the major cation in the samples was $\mathrm{Na}+\mathrm{K}$, while the major ion for anions was $\mathrm{Cl}$. Therefore, the dominant ions was $\mathrm{Na}-\mathrm{Cl}$, which can be categoried as marine and deep ancient water type. The mean concentrations of heavy metals of $\mathrm{Fe}, \mathrm{Mn}, \mathrm{Cu}$, and $\mathrm{Zn}$ was $0.53 \mathrm{mg} / \mathrm{l}, 0.20 \mathrm{mg} / \mathrm{l}, 0.01 \mathrm{mg} / \mathrm{l}$ and $0.04 \mathrm{mg} / \mathrm{l}$, respectively. All the selected heavy metal parameters met the Recommended Raw Water Standard by Ministry of Health, Malaysia[8]. Therefore, it can be concluded that the heavy metals in the study area will not give serious problem unless intense human interventions take place in the future. Evaluating the potential impacts, concerns, and assessing possible mitigation measures and monitoring are important steps for continuous protection of the groundwater in study area.

Authors would like to thank Ministry of Higher Education, Malaysia in funding the project through Fundamental Research Grant Scheme (FRGS) (Vote 1523). Also thank to Universiti Tun Hussein Onn Malaysia under Graduate Incentive Scheme (Vote U780) for providing financial support to the first author.

\section{References}

1. S. Suratman, "Managing the groundwater component in Malaysia," in Malaysia Water Partnership (MyWP), kuala lumpur: Minerals and Geoscience Department Malaysia, pp. 1-11, (2004).

2. N. Umar Kura, M. Firuz Ramli, W. N. Azmin Sulaiman, S. Ibrahim, A. Zaharin Aris, and A. Mustapha, "Evaluation of factors influencing the groundwater chemistry in a small tropical Island of Malaysia," Int. J. Environ. Res. Public Health, vol. 10, no. 5, pp. 1861-1881, (2013).

3. N. U. Kura, M. F. Ramli, W. N. A. Sulaiman, S. Ibrahim, and A. Z. Aris, "An overview of groundwater chemistry studies in Malaysia," Environ. Sci. Pollut. Res., no. December, pp. 1-19, (2015).

4. M. H. Abd Razak, Y., Abd Karim, "Groundwater in Malaysia Context," in Proceeding of the Groundwater Colloquium 2009, putrajaya, (2009).

5. S. Musa, N. A. Zakaria, L. T. Liang, and D. Tjahjanto, "Subsurface Conditions with Geo-hydraulic Properties : Empirical Evidence from Parit Raja, Johor," Int. Conf. Civ. Environ. Eng. Sustain. (IConCEES 2011), (2012).

6. P. Li, J. Wu, and H. Qian, "Hydrogeochemistry and quality assessment of shallow groundwater in the southern part of the yellow river alluvial plain (Zhongwei section), Northwest China," Earth Sci. Res. J., vol. 18, no. 1, pp. 27-38, (2015).

7. P. Li, H. Qian, J. Wu, Y. Zhang, and H. Zhang, "Major Ion Chemistry of Shallow Groundwater in the Dongsheng Coalfield, Ordos Basin, China," Mine Water Environ., vol. 32, no. 3, pp. 195-206, 2013.

8. M. O. H. Malaysia, “Drinking Water Quality Standard,” Engineering Services Division Ministry of Health Malaysia (2004).

9. JMG, "Geological Map of Peninsular Malaysia." retreive from : http://www.jmg.gov.my/add_on/mt/smnjg/tiles/, on 13 May (2018). 
10. M. Hazreek, Z. Abidin, A. Madun, S. Azhar, and A. Tajudin, "Evaluation of Unknown Tube Well Depth Using Electrical Resistivity Method," MATEC Web of Conferences 103, 07002, (2017).

11. M. H. Z. Abidin et al., "Forensic Assessment on Ground Instability Using Electrical Resistivity Imaging (ERI)," J. Phys., vol. 755, p. 011001, (2016).

12. APHA. Standard Methods for the Examination of Water and Wastewater, 22nd Edition, American Public Health Association, American Water Works Association, Water Environment Federation, (2012).

13. W. Weight, "Hydrogeology Field Manual", 2nd edition, New York, The McGraw-Hill Companies, Inc, (2008).

14. M. Radojevic and V. N. Bashkin, "Practical Environmental Analysia". RSC Publishing, (2006).

15. Z. Hamzah, A. Z. Aris, and M. F. Ramli, "Groundwater Quality Assessment Using Integrated Geochemical Methods, Multivariate Statistical Analysis , and Geostatistical Technique in Shallow Coastal Aquifer of Terengganu, Malaysia," Arab. J. Geosci., (2017).

16. A. M. Piper, "A graphic procedure in the geochemical interpretation of water," Eos, Trans. Am. Geophys. Union, vol. 25, no. 6, pp. 914-928, (1944).

17. Kumar, P. J. S., "Interpretation of groundwater chemistry using piperand Chadha ' $\mathrm{s}$ diagrams : a comparative study from Perambalur Taluk", Elixir Geoscience, vol 54, 12208-12211 (2014).

18. A. R. Samsudin, A. Haryono, U. Hamzah, and A. G. Rafek, "Salinity mapping of coastal groundwater aquifers using hydrogeochemical and geophysical methods: A case study from north Kelantan, Malaysia," Environ. Geol., vol. 55, no. 8, pp. 17371743, (2008).

19. C. M. Leung and J. J. Jiao, "Heavy metal and trace element distributions in groundwater in natural slopes and highly urbanized spaces in Mid-Levels area, Hong Kong," Water Res., vol. 40, no. 4, pp. 753-767, (2006).

20. R. Fitts, "Groundwater Science", 2nd edition, Elsevier, (2001).

21. N. M. Isa, A. Z. Aris, W. Y. L. Wan, W. N. A. W. Sulaiman, and S. M. Praveena, "Evaluation of heavy metal contamination in groundwater samples from Kapas Island, Terengganu, Malaysia," Arab J Geosci, vol 7:1087-1100, (2013). 